\title{
Responsiveness to acoustic stimulation, distribution and habitat preferences of the Lesser Spotted Woodpecker, Dendrocopos minor, in Friuli-Venezia Giulia (North-eastern Italy)
}

\author{
Gianluca Rassati
}

\begin{abstract}
From 2005 to 2013 in Friuli-Venezia Giulia (NE Italy), using the playback method, a study on the Lesser Spotted Woodpecker, Dendrocopos minor, was carried out. The aims were to identify the trends in distribution, the range, and the habitat preferences, along with the evaluation of the responsiveness to acoustic stimulation. The Lesser Spotted Woodpecker responded in $10.67 \%$ of the points where a conspecifics stimulus was emitted, demonstrating a "strong" responsiveness to the first stimulus. In the case of a response, males prevailed, and the Lesser Spotted Woodpecker was confirmed as the Picidae species that tended to show itself the most ( $79.17 \%$ of the points). Thanks to the tendency to expand the range and to occupy new zones within the known range, most of the suitable environments were occupied in the Provinces of Trieste and Gorizia and from the lowlands to the outer prealpine zone, even in urban areas. In the montane zone, expansion occurred through ascending of the valleys and slopes. The species was found from sea level to $1200 \mathrm{~m}$ (mean altitude: $429 \pm 270 \mathrm{SD}$ m a.s.1.) and particularly below $800 \mathrm{~m}$ a.s.l. (about $90 \%$ of the contacts). Of all the contacts, $71.69 \%$ occurred in broadleaf woodlands. Woodlands along watercourses were revealed to be very important (most highly represented forest type with more than one fifth of contacts), which have allowed the species to live in the lowlands and subsequently colonise other suitable environments, and the countryside and orchards, which are fundamental in the mountains for the spread and permanence of the taxon. In some areas, densities of 1.11-2.50 territories/100 ha were obtained. In Friuli-Venezia Giulia, a population of 150-190 pairs has been estimated, with an increase of just over $60 \%$ compared to the beginning of the century. Finally, some aspects concerning conservation-related problems are reported.
\end{abstract}

Key words: Dendrocopos minor, responsiveness, distribution, habitat preferences, density, population, conservation, Friuli-Venezia Giulia, North-eastern Italy.

Riassunto - Reattività alle stimolazioni sonore, distribuzione e preferenze ambientali del Picchio rosso minore, Dendrocopos minor, in Friuli-Venezia Giulia.

Dall'anno 2005 all'anno 2013 in Friuli-Venezia Giulia è stato condotto uno studio sul Picchio rosso minore, Dendrocopos minor, utilizzando il metodo del playback. Gli scopi erano l'individuazione delle

\section{Gianluca Rassati}

Via Udine 9, 33028 Tolmezzo (UD), Italia

E-mail: itassar@tiscali.it

(C) 2015 Gianluca Rassati

Received: September 20, 2014

Accepted for publication: December 12, 2014 tendenze distributive, dell'areale, delle preferenze ambientali e la valutazione della reattività alle stimolazioni sonore. Il Picchio rosso minore ha risposto nel $10.67 \%$ dei punti in cui è stata emessa stimolazione di conspecifici dimostrando una "forte" reattività alla prima stimolazione. In caso di risposta hanno prevalso i maschi e il Picchio rosso minore si è confermata la specie di Picidae che tende maggiormente a farsi vedere ( $79.17 \%$ dei punti). Grazie alla tendenza all'espansione dell'area le e all'occupazione di nuove zone all'interno dell'areale conosciuto, nelle Provincie di Trieste e Gorizia e dalla pianura alla zona prealpina esterna è stata occupata la maggior parte degli ambienti adatti, anche in aree urbane. In zona montana l'espansione si è avuta tramite la risalita delle valli e dei versanti. La specie è stata trovata dal livello del mare a $1200 \mathrm{~m}$ (Altitudine media: 429 \pm 270 DS m s.l.m.) ed in particolar modo al di sotto di $800 \mathrm{~m}$ s.l.m. (circa 90\% dei contatti). Il $71.69 \%$ dei contatti è avvenuto in boschi di latifoglie. Molto importanti si sono rivelati i boschi lungo i corsi d'acqua (tipo forestale più rappresentato con oltre $1 / 5$ dei contatti) che hanno permesso alla specie di vivere in pianura e successivamente di colonizzare gli altri ambienti adatti, e campagne e frutteti, fondamentali in montagna per la diffusione e la permanenza del taxon. In alcune aree sono state ricavate densità di 1.11-2.50 territori/100 ha. In Friuli-Venezia Giulia è stata stimata una popolazione di 150-190 coppie con un aumento, rispetto all'inizio del secolo, di poco oltre $60 \%$. Sono riportati infine alcuni aspetti inerenti le problematiche legate alla conservazione.

Parole chiave: Dendrocopos minor, reattività, distribuzione, preferenze ambientali, densità, popolazione, conservazione, Friuli-Venezia Giulia, Italia Nord-orientale.

\section{INTRODUCTION}

The Lesser Spotted Woodpecker, Dendrocopos minor, widely distributed in Europe and in a wide band of Central Asia where it reaches the Kamchatka, is widespread also in North Africa (Algeria, Tunisia) (del Hoyo et al., 2002).

The species is linked to the broadleaf woodlands or predominantly broadleaf ones and to the presence of old trees and large amounts of standing dead wood, conditions that are found in old and unmanaged woodlands (Cramp, 1985; Spitznagel, 1990; Olsson et al., 1992; Wiktander et al., 1992; Winkler et al., 1995; Mikusinski \& Angelstam, 1997; Olsson et al., 2001; Delahaye et al., 2002; del Hoyo et al., 2002; Angelstam et al., 2003; Gorman, 2004; Kosiński \& Kempa, 2007; Smith, 2007; Ćiković et al., 2008; Reif et al., 2008; Hogstad, 2009; Riemer, 2009; Charman et al., 2010; Lõhmus et al., 2010). Such conditions are often verified in the riparian woodlands (Spitznagel, 1990; Olsson et al., 1992; Wiktander et al., 
1992; Miranda \& Pasinelli, 2001; del Hoyo et al., 2002; Gorman, 2004; Hogstad, 2009; Riemer, 2009) that are moreover characterised by the presence of several species of trees with soft wood (Populus spp., Salix spp., Alnus spp.), considered by different authors as being preferred by the species (Spitznagel, 1990; Winkler et al., 1995; Miranda \& Pasinelli, 2001; Riemer, 2009).

The plurispecific stands are more selected by the species than the monospecific ones (cf. e.g. Wiktander et al., 2001a; Delahaye et al., 2002).

The playback method is a very efficient technique to permit the contact with Lesser Spotted Woodpecker and, in general, with woodpeckers (Bibby et al., 2000; Wiktander et al., 2001a; Gorman, 2004; Rassati, 2008; Charman et al., 2010).

The species was rarely studied in Italy, particularly not in the Alpine zone. In Friuli-Venezia Giulia, the Lesser Spotted Woodpecker, is a sedentary, breeding, and irregular migrant species (Rassati, 2005a) and its distribution has recently been studied by Rassati (2005a) who has also provided the first data regarding the habitat preferences. In recent years, a tendency has been observed to modify the range, and to occupy new areas, also thanks to the expansion towards higher elevations (Rassati, 2008; 2009).

The aims of this study were to identify the trends in distribution, the range, and the habitat preferences, along with the evaluation of the responsiveness to acoustic stimulation.

\section{STUDY AREAS AND METHODS}

The investigation involved the woodlands potentially suitable for the species in Friuli-Venezia Giulia (Northeastern Italy). All wooded areas were taken into consideration, from lowland woods to montane woodlands generally below $1200 \mathrm{~m}$ elevation.

Following the first definition of the range and habitat preferences (Rassati, 2005a) all the data regarding the Lesser Spotted Woodpecker were collected and entered into a database, in order to identify the trends in distribution and to improve the knowledge on their preferred habitats. This article is based on information collected from 2005 to 2013 .

The data were obtained using the playback method, from the beginning of February to the end of April, while during the rest of the year, visits were made aimed at making visual and/or acoustic contact, as well as searching for signs of its presence. The use of acoustic stimuli was limited because, similarly to other Picidae, the responsiveness is higher in a particular period of the year (Miranda \& Pasinelli, 2001; Wiktander et al., 2001a; Rassati, 2005a; 2008; Wübbenhorst \& Südbeck, 2003; Gorman, 2004; Hardersen, 2004; Wiggins, 2004; Charman et al., 2010).

Additional information was collected during the visits carried out for other purposes.

The playback method (Bibby et al., 2000) was used as reported below. The emission of the calls, obtained from Rochè (1990), was carried out with a broadcaster with $30 \mathrm{~W}$ of power that was slowly rotated by $360^{\circ}$. For each emission point, three acoustic stimuli were played, each lasting 90 seconds, with a pause of 30-40 seconds between each emission, and a listening period of $60 \mathrm{sec}-$ onds after the third stimulus. The stimuli were interrupted in the case of a response from the stimulated species. The distance between the emission points was variable, as it was characterised during the course of the visits according to the suitability of the habitat. The responses, the spontaneous contacts and their modalities, including other Picidae species (Wryneck (WR), Jynx torquilla; Grey-headed Woodpecker (GHW), Picus canus; Green Woodpecker (GW), Picus viridis; Black Woodpecker (BW), Dryocopus martius; Great Spotted Woodpecker (GSW), Dendrocopos major) with respect to the stimulated species (Lesser Spotted Woodpecker, (LSW)), were recorded on a specially designed datasheet and on a map. To determine the responsiveness to the acoustic stimuli, the following parameters were calculated:

A) response to stimuli by the species subject of the visit (ratio between the number of points in which a response occurred and the total number of points in which a stimulus was emitted);

B) response per single stimulus by the species subject of the visit (ratio between the number of responses per single stimulus and the total number of responses);

C) response to stimuli by Picidae species not subject of the visit (ratio between the number of points in which a response occurred and the total number of points in which a stimulus was emitted) in relation to all species and for each single species;

D) spontaneous contact with Picidae species not subject of the visit (ratio between the number of points in which a spontaneous contact occurred and the total number of surveyed points) in relation to all species and for each single species;

E) induced or spontaneous contact with Picidae (ratio between the number of points in which Picidae were contacted and the total number of surveyed points) in relation to all species and for each single species (for the Lesser Spotted Woodpecker, obviously only the induced contacts were considered).

For the purposes of determining the distribution and the habitat preferences, for each contact elevation, aspect and forest type were recorded. Only the contacts having a minimum distance of $500 \mathrm{~m}$ from each other were taken into account.

In Tab. 1, the types of environment in which the Lesser Spotted Woodpecker was found are reported, for the woodlands, the species that characterise them are listed. For the stands characterised by the coexistence of different broadleaf species (sometimes even coniferous), in various percentages according to the site characteristics, where no species clearly prevails, so that it was not possible to attribute a specific forest type, the main potential species have been indicated, therefore grouping the contacts that occurred in woodlands with similar composition into a single type.

These woodlands are the following:

1) mixed broadleaf woodland (C. betulus, Quercus spp., C. sativa etc.) sometimes with Norway spruce, $P i$ cea abies, and Scots pine, Pinus sylvestris, which mainly grow in the prealpine or outer Alpine area (MBW1); 
2) mixed broadleaf woodland (Quercus spp., $O$. carpinifolia, F. ornus etc.) sometimes with Black Pine, Pinus nigra, which mostly grows in the Provinces of Trieste and Gorizia (MBW2);

3) woodland characterised by Black Poplar, Populus nigra, and/or Willows, Salix spp., and/or Alders, Alnus spp., and other broadleaf trees that grow along watercourses and lakes, and as well as occupying the riparian belt, is also located in the zone behind, generally bordering the countryside (RW1);

4) same type of woodland as the preceding one, characterised by the (sometimes predominant) presence of coniferous trees such as Pinus spp. and Picea abies. It also differs from the preceding one because it is usually located in the montane zone (RW2).

In some sample areas, the density (territories/100 ha) was obtained by the execution of three censuses in the early part of the breeding period (prior to egg laying) using playback at points placed at varying distances from each other, according to the species being surveyed and the site characteristics. The tree species indicated in Tab. 2 are those that characterise the single areas in their entirety. In the case in which the type of woodland was attributable to one of the four described above, this is reported in the table.

Tab. 1 - Subdivision of the contacts in relation to the environment types. / Suddivisione dei contatti in rapporto ai tipi di ambiente.

\begin{tabular}{|c|c|c|}
\hline & $\mathbf{N}$ & $\mathbf{F \%}$ \\
\hline Populus nigra, Salix spp., Alnus spp., Fraxinus ornus, Robinia pseudacacia (RW 1) & 25 & 15.06 \\
\hline $\begin{array}{l}\text { Carpinus betulus, Quercus petraea, Quercus pubescens, Quercus robur, Castanea sativa, Fraxinus ornus, } \\
\text { Ostrya carpinifolia, Acer pseudoplatanus, Tilia spp., Fraxinus excelsior, Fagus sylvatica (MBW1) }\end{array}$ & 23 & 13.86 \\
\hline Countryside-Orchard & 21 & 12.65 \\
\hline Populus nigra, Salix spp., Alnus spp., Fraxinus ornus, Robinia pseudacacia, Pinus sylvestris, Picea abies (RW 2) & 10 & 6.02 \\
\hline Quercus petraea, Castanea sativa & 9 & 5.42 \\
\hline $\begin{array}{l}\text { Quercus cerris, Quercus petraea, Quercus pubescens, Ostrya carpinifolia, Fraxinus ornus, Acer campestre, } \\
\text { Ulmus minor, Celtis australis, Tilia spp., Castanea sativa (MBW2) }\end{array}$ & 5 & 3.01 \\
\hline Populus nigra & 4 & 2.41 \\
\hline Quercus robur, Carpinus betulus & 4 & 2.41 \\
\hline Park-Garden & 4 & 2.41 \\
\hline Ostrya carpinifolia, Fraxinus ornus & 4 & 2.41 \\
\hline Quercus petraea & 4 & 2.41 \\
\hline Castanea sativa & 4 & 2.41 \\
\hline Fagus sylvatica & 4 & 2.41 \\
\hline Fagus sylvatica, Carpinus betulus & 4 & 2.41 \\
\hline Quercus pubescens, Fraxinus ornus, Ostrya carpinifolia & 3 & 1.81 \\
\hline Castanea sativa, Carpinus betulus & 3 & 1.81 \\
\hline Castanea sativa, Tilia cordata, Acer pseudoplatanus & 3 & 1.81 \\
\hline Quercus petraea, Picea abies & 3 & 1.81 \\
\hline Quercus petraea, Fagus sylvatica, Pinus sylvestris, Picea abies & 3 & 1.81 \\
\hline Acer pseudoplatanus, Fraxinus excelsior & 3 & 1.81 \\
\hline Fagus sylvatica, Castanea sativa, Fraxinus excelsior & 3 & 1.81 \\
\hline Pinus sylvestris, Fraxinus ornus, Robinia pseudacacia & 3 & 1.81 \\
\hline Quercus robur, Ulmus minor, Fraxinus oxycarpa, Carpinus betulus & 2 & 1.20 \\
\hline Quercus pubescens & 2 & 1.20 \\
\hline Alnus glutinosa & 2 & 1.20 \\
\hline Fagus sylvatica, Tilia cordata, Fraxinus excelsior & 2 & 1.20 \\
\hline Fagus sylvatica, Picea abies & 2 & 1.20 \\
\hline Quercus pubescens, Fraxinus ornus, Ostrya carpinifolia, Pinus nigra & 1 & 0.60 \\
\hline Quercus robur, Alnus glutinosa, Robinia pseudacacia & 1 & 0.60 \\
\hline Acer pseudoplatanus, Tilia cordata & 1 & 0.60 \\
\hline Fagus sylvatica, Ostrya carpinifolia & 1 & 0.60 \\
\hline Fagus sylvatica, Fraxinus ornus, Ostrya carpinifolia & 1 & 0.60 \\
\hline Fagus sylvatica, Pinus sylvestris & 1 & 0.60 \\
\hline Fagus sylvatica, Pinus nigra & 1 & 0.60 \\
\hline
\end{tabular}


Tab. 2 - Densities (territories/100 ha) in some areas. / Densità (territori/100 ha) in alcune aree.

\begin{tabular}{|l|l|l|c|c|}
\hline \multicolumn{1}{|c|}{ Area } & Coordinates & \multicolumn{1}{|c|}{ Forest type } & $\begin{array}{c}\text { Surface } \\
\text { area (ha) }\end{array}$ & Density \\
\hline $\begin{array}{l}\text { Bars } \\
\text { (Friulan Plain) }\end{array}$ & $\begin{array}{l}46^{\circ} 14^{\prime} \mathrm{N} \\
13^{\circ} 03^{\prime} \mathrm{E}\end{array}$ & Populus nigra, Alnus glutinosa (RW1) & 120 & 2.50 \\
\hline $\begin{array}{l}\text { Isonzo } \\
\text { (Friulan Plain) }\end{array}$ & $\begin{array}{l}45^{\circ} 54^{\prime} \mathrm{N} \\
13^{\circ} 32^{\prime} \mathrm{E}\end{array}$ & Populus nigra, Salix spp. (RW1) & 80 & 2.50 \\
\hline $\begin{array}{l}\text { Montenars } \\
\text { (Julian Prealps) }\end{array}$ & $\begin{array}{l}46^{\circ} 16^{\prime} \mathrm{N} \\
13^{\circ} 12^{\prime} \mathrm{E}\end{array}$ & $\begin{array}{l}\text { Fraxinus excelsior, Acer pseudoplatanus, Alnus glutinosa, } \\
\text { Castanea sativa } \text { (MBW1) }\end{array}$ & 255 & 2.35 \\
\hline $\begin{array}{l}\text { Quattro Venti } \\
\text { (Friulan Plain) }\end{array}$ & $\begin{array}{l}46^{\circ} 08^{\prime} \mathrm{N} \\
13^{\circ} 09^{\prime} \mathrm{E}\end{array}$ & Quercus robur, Alnus glutinosa, Robinia pseudacacia & 55 & 1.82 \\
\hline $\begin{array}{l}\text { Erbezzo Valley } \\
\text { (Julian Prealps) }\end{array}$ & $\begin{array}{l}46^{\circ} 08^{\prime} \mathrm{N} \\
13^{\circ} 35^{\prime} \mathrm{E}\end{array}$ & Castanea sativa, Ostrya carpinifolia (MBW1) & 180 & 1.67 \\
\hline $\begin{array}{l}\text { Cosa Valley } \\
\text { (Carnic Prealps) }\end{array}$ & $\begin{array}{l}46^{\circ} 14^{\prime} \mathrm{N} \\
12^{\circ} 54^{\prime} \mathrm{E}\end{array}$ & $\begin{array}{l}\text { Fagus sylvatica, Castanea sativa, Fraxinus excelsior, Acer } \\
\text { pseudoplatanus } \text { (MBW1) }\end{array}$ & 250 & 1.60 \\
\hline $\begin{array}{l}\text { Muiè } \\
\text { (Carnic Prealps) }\end{array}$ & $\begin{array}{l}46^{\circ} 13^{\prime} \mathrm{N} \\
12^{\circ} 44^{\prime} \mathrm{E}\end{array}$ & Fraxinus excelsior, Quercus spp., Castanea sativa (MBW1) & 225 & 1.33 \\
\hline $\begin{array}{l}\text { But Valley } \\
\text { (Carnic Alps) }\end{array}$ & $\begin{array}{l}46^{\circ} 26^{\prime} \mathrm{N} \\
13^{\circ} 00^{\prime} \mathrm{E}\end{array}$ & MBW1 with Picea abies & 90 & 1.11 \\
\hline
\end{tabular}

\section{RESULTS}

Acoustic stimuli were played in 675 stations, and the species responded in $72(10.67 \%)$ stations (Parameter A).

The percentage of responses per single stimulus $(\mathrm{Pa}-$ rameter $\mathrm{B}$ ) decreased, in a definite manner, in order of emission (Tab. 3).

In the case of a response, when it was possible to determine the sex, males prevailed (this was also verified in the case of a response by Great Spotted Woodpecker), followed by females and then by pairs.

Sighting occurred in $79.17 \%$ of the points in which there was a response, while both song (the sound "Kii-Kii-Kii-KiiKii" or "Gii-Gii-Gii-Gii-Gii") and drumming were heard in $45.83 \%$ of the points. Song and drumming were often heard in association, as reported by del Hoyo et al. (2002).

In $16.00 \%$ of the stations, a response from other Picidae species was obtained (GSW 9.78\%, GW 2.67\%, GW-GSW 1.78\%, GHW 0.44\%, BW 0.44\%, GHW-GSW 0.44\%, BW-GSW 0.44\%) (Parameter C).

In $16.44 \%$ of the stations, a spontaneous contact with other Picidae species occurred (GSW 6.22\%, GW 5.78\%, BW 1.78\%, GW-GSW 1.33\%, GHW 0.44\%, BW-GSW 0.44\%, WR-GW-GSW 0.44\%) (Parameter D).

Tab. 3 - Percentage frequency of responses per single stimulus. / Frequenza percentuale di risposte per singola stimolazione.

\begin{tabular}{|c|c|}
\hline Stimulus No. & F\% \\
\hline 1 & 45.83 \\
\hline 2 & 33.33 \\
\hline 3 & 20.83 \\
\hline
\end{tabular}

Picidae were contacted in $35.11 \%$ of the stations (GSW 12.00\%, LSW 5.78\%, GW 5.33\%, GW-GSW 4.00\%, GSW-LSW 1.78\%, BW 1.33\%, GW-LSW 1.33\%, BW-LSW 0.89\%, GHW 0.44\%, BW-GSW 0.44\%, WRGHW-GSW 0.44\%, GHW-GSW-LSW 0.44\%, GW-BWGSW 0.44, GW-GSW-LSW 0.44\%) (Parameter E).

The responsiveness of the Lesser Spotted Woodpecker increased from February (10.67\%) to March (12.24\%) and then decreased in April (7.69\%) (Fig. 1). Responses also occurred at temperatures approaching $0^{\circ} \mathrm{C}$.

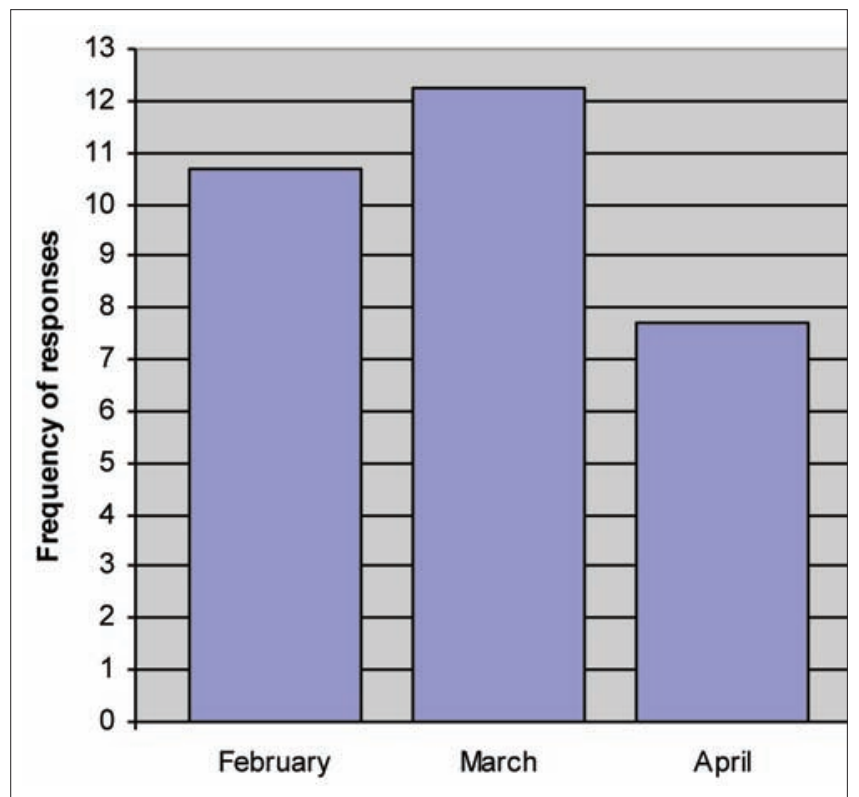

Fig. 1 - Monthly percentage frequency of responses. / Frequenza percentuale mensile di risposte. 
In $4.89 \%$ of the points in which a stimulus was emitted, a response by the Eurasian Nuthatch, Sitta europaea, was verified.

On some occasions, during the stimuli, individuals of some species were observed (e.g. Marsh Tit, Poecile palustris, Hawfinch, Coccothraustes coccothraustes) approaching and stopping at a limited distance, observing the operator for the entire duration of the stimuli.

The spontaneous contacts with the species were 94 .

The Lesser Spotted Woodpecker is less widespread than it appears in Fig. 2, especially in the central-southern sector, and particularly in the lowland zones, where it is missing from large areas devoid of suitable habitat, as they are occupied by urban and industrial areas or intensive agriculture. It is more evenly widespread in the prealpine zone, along river courses (even in lowlands) and, in the mountains, in valley floors and at rural zones.

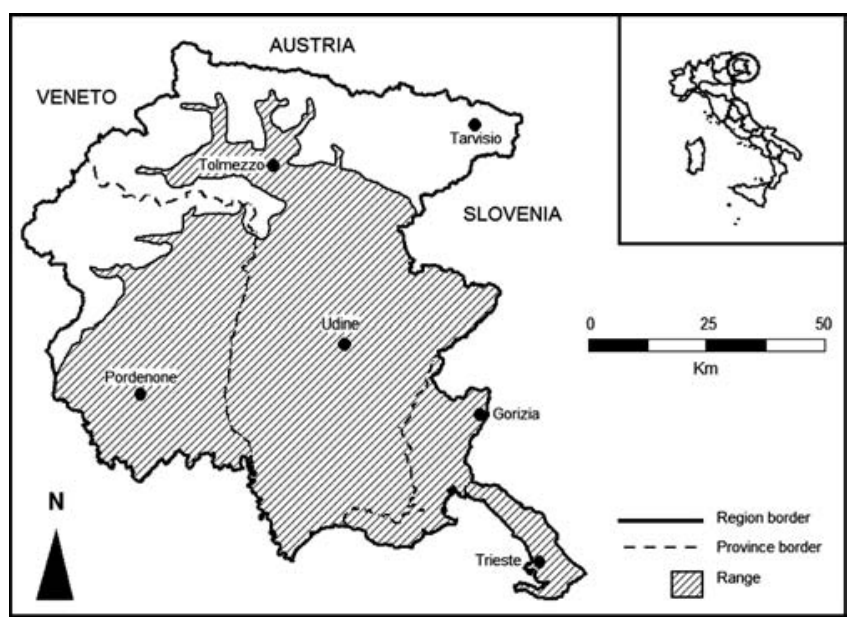

Fig. 2 - Range of Dendrocopos minor in Friuli-Venezia Giulia. / Areale di Dendrocopos minor in Friuli-Venezia Giulia.
Occasionally, the species was observed in Cansiglio, in Valcanale and in the highest sector of the valleys in Carnia, in the Canal del Ferro and in the Cellina Valley.

It is estimated that there are 150-190 pairs of Lesser Spotted Woodpecker in Friuli-Venezia Giulia with an increase of just over $60 \%$ compared to the beginning of the century.

Similarly to what was reported by del Hoyo et al. (2002) for Europe, the Lesser Spotted Woodpecker in Friuli-Venezia Giulia was found from sea level to 1200 m (mean altitude: $429 \pm 270$ SD m a.s.1.) and particularly below $800 \mathrm{~m}$ a.s.l. (about $90 \%$ of the contacts; Fig. 3).

The types of frequented woodlands were particularly those of broadleaf trees, where $71.69 \%$ of the contacts occurred (Tab. 1). The woodlands along watercourses and lakes were the most represented forest type with, in total, more than one fifth of the contacts between the two variants (RW1 and RW2). The mixed broadleaf woodland of the prealpine or outer Alpine area were also well represented (13.86\%) along with countryside-orchard (12.65\%). The species was also found in parks and gardens (2.41\%). The mixed coniferous and broadleaf woodlands and coniferous ones appeared to be less selected: with the exception of that along watercourses and lakes $(6.02 \%)$ the percentage frequency was less than 2 .

The stations in which the species was found were divided almost equally between flat zones $(51.81 \%)$ and sloped zones $(48.19 \%)$. In the latter, the percentage frequencies of aspects ranged from a minimum of 3.01 (W and NW) to a maximum of 7.83 (E, NE, S) (Fig. 4).

Breedings were found in Salix spp., Populus nigra, Walnut, Juglans regia, Common Hornbeam, Carpinus betulus, Sweet Chestnut, Castanea sativa, Pedunculate Oak, Quercus robur, Sessile Oak, Quercus petraea, Apple Tree, Malus domestica, European Pear, Pyrus communis, Wild Cherry, Prunus avium, Littleleaf Linden, Tilia cordata, Largeleaf Linden, Tilia platyphyllos.

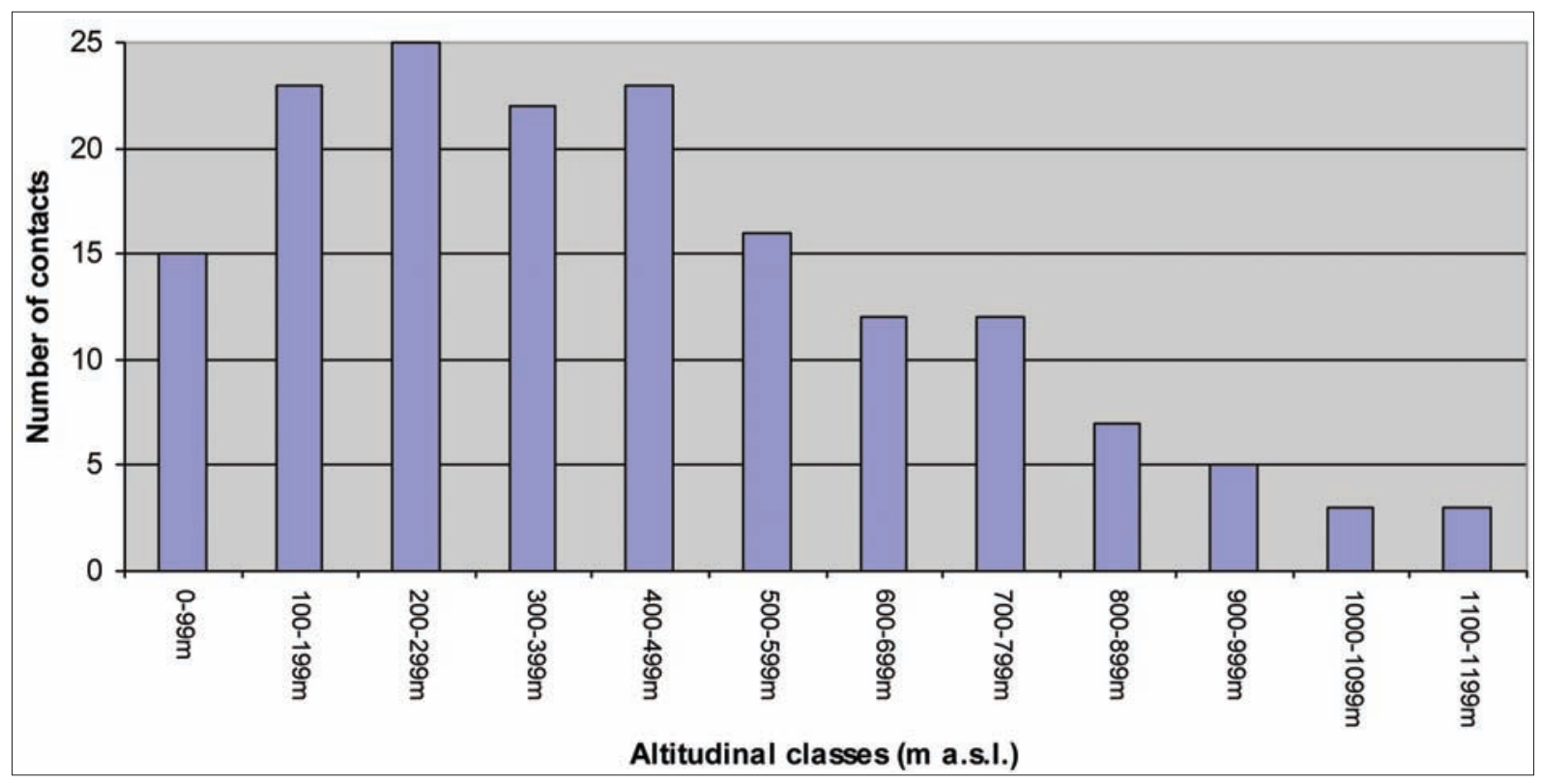

Fig. 3 - Subdivision of the contacts into altitudinal classes. / Suddivisione dei contatti in classi altitudinali. 


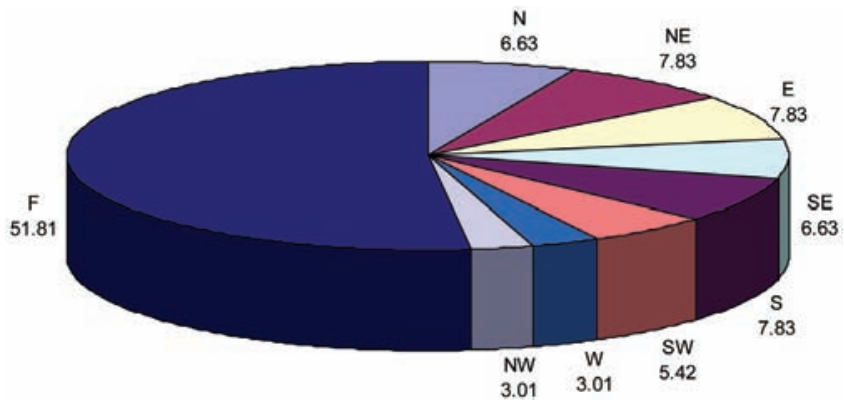

Fig. 4 - Percentage frequency of the contacts in relation to the aspect. / Frequenza percentuale dei contatti in rapporto all'esposizione. $\mathrm{F}=$ flat. / pianeggiante.

In the investigated areas, the density (territories/100 ha) comprised values between 1.11 and 2.50 (Tab. 2) and the territories were located in zones with very variable slopes: from flat areas to steep slopes. In some cases, it was possible to verify that the territory included wide clearings.

\section{DISCUSSION}

\section{Responsiveness}

Whilst the use of playback to locate the Lesser Spotted Woodpecker is the most efficient method (Rassati, 2014b), the number of spontaneous contacts $(57 \%)$ exceeded that of induced contacts $(43 \%)$ given the limited time period in which the stimuli were emitted. The frequency of response $(10.67 \%)$ was similar or less than that obtained in two studies carried out in Carnia (Rassati, 2008; 2014b). The higher value attributable to the second study just cited is due to the fact that the subject of this investigation was an area where the picid had a relatively high density, while in this study, the researches aimed to find the species and therefore zones uninhabited or scarcely used by the taxa were also monitored. This latter factor is probably at the origin of the higher frequency of response verified by Miranda \& Pasinelli (2001) in north-eastern Switzerland. Comparison with a study that used the same methodology in Friuli-Venezia Giulia (Rassati, 2014a) shows that the Lesser Spotted Woodpecker responded with greater frequency than the Three-toed Woodpecker, Picoides tridactylus, $(7.65 \%)$ and with a lower percentage than that of the Grey-headed Woodpecker (13.23\%). The scarce "trend" of the Three-toed Woodpecker to respond to acoustic stimuli, and conversely, the good responsiveness of the Grey-headed Woodpecker (Rassati, 2014a) can explain the differences with the Lesser Spotted Woodpecker.

The percentage of responses per single stimulus was similar (stimuli 1 and 3) or equal (stimulus 2) to that of a study carried out in Carnia demonstrating a "strong" responsiveness to the first stimulus, a fact in common with the Great Spotted Woodpecker (Rassati, 2008).

The percentage of points in which a response by other Picidae species was verified $(16.00 \%)$ was similar to what was verified in an area in Carnia (Rassati, 2008). The Great Spotted Woodpecker was the species that responded most to the calls and in more stations (12.44\%) to the call of Lesser Spotted Woodpecker of the latter (10.67\%), confirming the disposition to frequently utter audible sounds, even over a great distance, the good responsiveness to acoustic stimula- tion, the lack of empty spaces between the territories, and the good level of vigilance of the owners throughout the entire territory (Rassati, 2014b). Moreover, the Great Spotted Woodpecker is the most common woodpecker species in Friuli-Venezia Giulia and is the most responsive to acoustic stimulation (Rassati, 2008; 2014b). The emission of Lesser Spotted Woodpecker calls in Friuli-Venezia Giulia induced more responses of other Picidae species compared to what was verified for the Grey-headed Woodpecker (14.73\%) and the Three-toed Woodpecker (12.94\%) (Rassati, 2014a). This is due to the high number of responses of the species most similar to the Lesser Spotted Woodpecker, namely the Great Spotted Woodpecker $(12.44 \%$; thanks also to the factors mentioned above) while for the Grey-headed Woodpecker and the Three-toed Woodpecker, the frequency of responses of the most responsive species, the Black Woodpecker, was lower: $5.91 \%$ and $8.53 \%$, respectively (Rassati, 2014a).

The percentage of points in which there was spontaneous contact with other Picidae species (16.44\%) was slightly less than what was found in an area in Carnia(Rassati,2008).

In accordance with the fact that the males generally tend to manifest possession of the territory and to defend it more and with greater frequency than the females (Cramp, 1985; Winkler et al., 1995; Rassati, 2008), in the case of a response to conspecifics stimuli, when it was possible to determine the sex, males prevailed, as well as in the case of responses by Great Spotted Woodpecker. However, only a slightly lower responsiveness was recorded for females compared to males, especially in the early part of the breeding period, probably due to strong intrasexual competition (Wiktander et al., 2000) but also due to females not yet stabilised in a territory and looking for a partner.

The Lesser Spotted Woodpecker was confirmed as the Picidae species which is most likely to show itself in the case of a response, indeed, it occurred in $79.17 \%$ of the points (this study) against $33.33 \%$ of the Grey-headed Woodpecker and $15.38 \%$ of the Three-toed Woodpecker (Rassati, 2014a).

The responsiveness (Fig. 1) resulted as being similar to that obtained in an area in Carnia in March and April, and not comparable in February when it was not found in the comparative study area (Rassati, 2008) as in the period in which the research was carried out (1993), the species was less widespread and the localisation in the Alpine zone, together with the minor effect of climate change with respect to today (anticipation of the breeding season), induced a much lower probability of a response in February. Contrary to what was reported by Miranda \& Pasinelli (2001), Wiktander et al. (2001b), Gorman (2004) and Charman et al. (2010), February also resulted as being suitable for investigating the species, with a frequency of response greater than that of April, when, in the second half of the month, the responses tended to decrease. In addition to the anticipation reported above of the breeding season, it is believed that this is also due to the difference in localisation (thanks to the latitude, despite being "mitigated" by the increase in the elevation in the case of investigations in the montane sector, and the proximity to the Mediterranean Sea) with respect to the studies cited, given that in February responses were even obtained in the Alpine area.

In general, the Lesser Spotted Woodpecker has proven to be very responsive; this was also confirmed by tests carried 
out using playback in the presence of individuals in the vicinity that promptly responded, with very high frequency, in agreement with the high territoriality and territorial fidelity over the years and the seasons (cf. Wiktander et al., 2001a).

The above results confirm frequent interspecific interactions (Cramp, 1985; Winkler et al., 1995; del Hoyo et al., 2002; Gorman, 2004; Rassati, 2008; 2014a). Moreover, in some points, three Picidae species were contacted at the same time, and individuals of these taxa (which were also males) were observed to manifest the possession of the territory at the same time, even at a distance of a few tens of metres away, without further interactions other than the acoustic one.

To prove that a group responsiveness exists in the Picidae, caused by common acoustic stimuli, it was interesting to verify that, as was the case for Grey-headed Woodpecker and Three-toed Woodpecker (Rassati, 2014a), Grey-headed Woodpecker, Green Woodpecker, Black Woodpecker, and Great Spotted Woodpecker all responded, even outside the range of the Lesser Spotted Woodpecker. In addition, the Lesser Spotted Woodpecker responded to Grey-headed Woodpecker stimuli in areas where the second species was absent (Rassati, 2014a).

The frequency of response by the Eurasian Nuthatch (4.89\%) resulted as being second only to that of the Great Spotted Woodpecker $(12.44 \%)$ and greater than that of the Green Woodpecker (4.45\%); this frequency is greater than that which was verified in Friuli-Venezia Giulia to the stimuli of Grey-headed Woodpecker $(2.67 \%)$ and Three-toed Woodpecker (1.47\%) (Rassati, 2014a), probably thanks to the higher ecological niche affinity and to the higher coincidence of the ranges (especially with respect to Three-toed Woodpecker) of the Lesser Spotted Woodpecker and the Eurasian Nuthatch.

\section{Distribution and habitat preferences}

From the comparison with the range described by Rassati (2005a), during the course of the last decade the tendency of the Lesser Spotted Woodpecker to occupy new areas has been recorded, similarly to what was found for Greyheaded Woodpecker and Three-toed Woodpecker (Rassati, 2014). This expansion has been considerable as most of the suitable environments in the Provinces of Trieste and Gorizia, and from the lowlands to the outer prealpine zone have become occupied, so that it is now relatively easy to contact the species that has also been found within some urban zones where it uses parks, gardens and wooded areas of a certain extension with old trees. In the montane zone, the expansion has occurred by means of ascending the valleys and slopes. This phenomenon, which is still in place, and has also been verified in the neighbouring Veneto (Rassati, 2012), has led the species to approach the heads of the valleys and has allowed contact in some of the larger urban areas. The occasional observations that occurred outside the range (see Results), despite not proving the existence of stable territories in these zones, are further evidence of the ongoing dynamics. Even within the known range, the species has colonised new zones, similarly to what has been recorded for other woodpecker species (Rassati, 2008; 2009; 2014a) and certainly favoured by the ageing and expansion of the woodlands. In the sparsely forested areas of Karst, it seemed to be positively influenced by the vegetation co- inciding with the dolines, as it is more developed than the surrounding vegetation (Rassati, 2005a).

Given what has been reported above, it will be interesting to observe for how long the taxon will still expand and increase in number and where it will reach, both in terms of altitude and in the penetration of the valleys since, unlike other species of Picidae, there are suitable habitats above the observed altitudinal limits (Rassati, 2005b; 2009).

A study conducted in the 1980s on breeding birds in Italy (Meschini \& Frugis, 1993) indicated the Lesser Spotted Woodpecker as being absent in Friuli-Venezia Giulia. In reality, the species was already present in Carnia at the end of the 1970s where the first breeding was established in 1989 in the locality of "Fol" in the municipality of Socchieve (Carnic Alps) (Rassati, unpubl. data). At the end of the 1990s and the early years of this century, the picid was already fairly evenly widespread in the outer prealpine zone: breeding was confirmed on the Julian Prealps in 1998 on Mount Chiastellirs in the municipality of Montenars and on the Carnic Prealps in 2000 near the hamlet of Cornial in the municipality of Clauzetto (Rassati, unpubl. data).

The ongoing expansion contrasts with the decline registered in many European countries (Tiainen, 1985; Nilsson et al., 1992; Wiktander et al., 1992; Mikusinski \& Angelstam, 1997; Julliard \& Jiguet, 2005; Hewson et al., 2007). In northern Europe, due to forest management sensu lato, there has been a negative trend in the past, determined by the loss of suitable habitat, a decrease in the quality of the remaining habitat and the fragmentation of the same (Tiainen, 1985; Wiktander et al., 1992); in the last 10-15 years, thanks to the modification of forestry practices, some populations have stabilised or increased (Ottvall et al., 2009; Gohli et al., 2011). In north-eastern Italy, the abandonment of silvicultural practices due to the decrease of human Alpine and rural populations, and to changes in lifestyle, increased costs, and loss of the value of timber, has favoured Picidae (cf. Rassati, 2014a). The Lesser Spotted Woodpecker being linked to the presence of old trees and large amounts of standing dead wood (Spitznagel, 1990; Olsson et al., 1992; Wiktander et al., 1992; Winkler et al., 1995; Mikusinski \& Angelstam, 1997; Delahaye et al., 2002; Angelstam et al., 2003; Gorman, 2004; Kosiński \& Kempa, 2007; Smith, 2007; Hogstad, 2009; Riemer, 2009; Charman et al., 2010; Lõhmus et al., 2010; Rassati, pers. obs.) has benefited from this abandonment that has caused the ageing and the increase of structural diversity of woodlands, and the reduction of the fragmentation of suitable habitat. This last factor has resulted in being very important, especially in the lowlands, where the simplification and environmental monotonisation have greatly reduced the possibility of life of the species.

The preference of the Lesser Spotted Woodpecker towards old, unmanaged deciduous woodlands is known (Spitznagel, 1990; Olsson et al., 1992; Wiktander et al., 1992; Gorman, 2004) and is one of the keys of the success that the species is obtaining in the study area.

Other factors that will undoubtedly favour picid in the future are the cutting of coniferous plantations dating back to the 1950s-1980s and climate change, which are favouring the replacement of conifers with broadleaf trees in the Alps, especially at lower elevations. 
Confirming what has already been verified (Rassati, 2005a) and generally reported (Cramp, 1985; Spitznagel, 1990; Wiktander et al., 1992; Winkler et al., 1995; Olsson et al., 2001; del Hoyo et al., 2002; Gorman, 2004; Kosiński \& Kempa, 2007; Ćiković et al., 2008; Reif et al., 2008; Riemer, 2009; Charman et al., 2010), the woodlands in which the Lesser Spotted Woodpecker is most widespread are the broadleaf, or predominantly broadleaf ones. The woodlands along watercourses have been revealed to be very important (total percentage frequency: 21.08; Tab. 1) as they have allowed the species to live in the lowlands and subsequently colonise other suitable environments; furthermore the countryside and orchards $(12.65 \%)$ have been shown to be fundamental in the mountains for the spread and permanence of the taxon. The old orchards are also considered important by other authors (e.g. Cramp, 1985; del Hoyo et al., 2002) but, in this case, they are of particular importance in montane zones, where the short width of the valley floor does not allow the development of suitable stands, not even along the main watercourse, and on the slopes unsuitable woodlands are found as they are purely or prevalently coniferous or young. Two other types of woodlands that are selected with a good frequency are the mixed broadleaf woodland (MBW1, 13.86\%; Tab. 1) and that of Quercus petraea and Castanea sativa (5.42\%), widely found in the prealpine zone. The monospecific stands of conifers, especially if artificial and formed by young and thin plants and of high density, generally appeared to be avoided by the species. The plurispecific stands, instead, as found in other zones of Europe (cf. e.g. Wiktander et al., 2001a; Delahaye et al., 2002) resulted as being the most chosen. The link with the Oaks, Quercus spp. (Smart et al., 2007; Charman et al., 2010), despite being well represented (cf. Tab. 1) in north-eastern Italy, is less strong as in the lowlands there are only residual patches of the original forest of Quercus, Carpinus, Ulmus and Fraxinus, in the mountains Oaks are scarcely represented, especially towards the inner zone, the picid prefers woodlands along watercourses that are scarce in Oaks, especially in the montane area; conversely, in other European zones, the Lesser Spotted Woodpecker prefers Oak woodlands at low elevation, still widespread (see reference just cited). The riparian woodlands are reported to be widely populated by the species (Spitznagel, 1990; Olsson et al., 1992; Wiktander et al., 1992; Miranda \& Pasinelli, 2001; del Hoyo et al., 2002; Gorman, 2004; Hogstad, 2009; Riemer, 2009) thanks to their lack of management that allows the presence of large continuous areas characterised by old trees of large dimensions and a lot of dead wood: in Friuli-Venezia Giulia, these woodlands were of primary importance, in addition to allowing the species to live, they were also zones from which the colonisation of other lowland areas started, in a context of source-sink dynamics.

The presence of environments considered "marginal" and of unmanaged areas has proved to be important: the use of reed-beds and species of minor economic relevance (e.g. Rowan, Sorbus aucuparia, Whitebeam, Sorbus aria, Plums, Prunus spp., Elder, Sambucus nigra, including fruits), was in fact verified as a trophic source, especially in autumn and winter.

The occupation of areas at higher elevations and the extension of the researches in previously uninvestigated zones have allowed the discovery, albeit with low frequency, of the Lesser Spotted Woodpecker above 1000 m a.s.l. (Fig. 3).
The mean altitude of $429 \mathrm{~m}$ a.s.1., however, indicates that the taxon prefers the lowest zone of the elevations and of the valley floors. Moreover, as for the Grey-headed Woodpecker (Rassati, 2014a), these results are determined by the current distribution of woodlands; indeed it is of the opinion that, if the plain was mostly wooded, it would be largely colonised (cf. e.g. Cramp, 1985; Winkler et al., 1995; Gorman, 2004; Reif et al., 2008; Riemer, 2009; Wesołowski, 2011). In confirmation of this, is also the high frequency of contacts below $200 \mathrm{~m}$ a.s.l. $(22.89 \%)$, even though the lowland zones, as mentioned above, contain large areas devoid of suitable habitat.

The high percentage frequency of stations located in flat zones $(51.81 \%$; Fig. 4) with respect to Grey-headed Woodpecker $(8.06 \%)$ and Three-toed Woodpecker (8.82\%) (Rassati, 2014a) indicates the preference of the Lesser Spotted Woodpecker for less sloping zones compared to those chosen by the other two woodpeckers. To this result, stations contributed that were located in highlands and in low-sloping areas along the slopes.

The results obtained in this study confirm that in FriuliVenezia Giulia, the Lesser Spotted Woodpecker lives in an altitudinal range that, although it is wide, is less extensive than that of the Grey-headed Woodpecker, the Green Woodpecker, the Black Woodpecker and the Great Spotted Woodpecker, and is similar to that of the Wryneck and the Three-toed Woodpecker (Rassati, 2005b; 2009; 2014a; unpubl. data) even if, compared to the latter species, which frequents montane and subalpine woodlands mostly dominated by coniferous trees, it presents an opposite altitudinal distribution, mainly breeding in woodlands dominated by broadleaf trees, from sea level to mid-mountain level. In addition, in Friuli-Venezia Giulia, the Lesser Spotted Woodpecker was found in syntopy with all the other species of Picidae with the exception of the Three-toed Woodpecker.

\section{Density, population and conservation}

The densities of the Lesser Spotted Woodpecker were variable (Tab. 2) and fell within or close to the range obtained in two other areas of the Carnic Alps (both in the Tagliamento Valley: 0.77-2.31 territories/100 ha, Rassati, 2008; 2014b; 1.12 territories/100 ha, Rassati, 2009). In the last decade, especially in the zones at the boundaries of the range, a trend towards an increase in the density has been confirmed, which was already verified in the previous decade (Rassati, 2008). The values (Tab. 2) fall within the range reported by other authors: 0.01-0.06 territories/100 ha (western Norway; Stenberg \& Hogstad, 1992), 0.821.50 pairs/100 ha (central Lithuania; Brazaitis \& Pètelis, 2010), 1.50-2.20 pairs/100 ha (western Poland; Kosiński \& Kempa, 2007), 1.60 pairs/100 ha (south-western Germany; Spitznagel, 1990), 1.60-2.40 territories/100 ha (eastern Austria; Riemer, 2009), 2.7-3.1 territories/100 ha (central Italy; Guerrieri \& Castaldi, 2003), 2-5 pairs/100 ha (Białowieża Forest, Poland; Wesołowski et al., 2002).

The expansion of the range and the consolidation of the population are also due to the increase in numbers.

The current phase of growth of the species should not encourage the belief that there is an apparent lack of problems regarding conservation. As well as what has been reported for Grey-headed Woodpecker and Three-toed Woodpecker (Rassati, 2014a) which the reader is invited to view, it is 
believed that for the Lesser Spotted Woodpecker it is necessary to pay special attention to avoid further elimination, fragmentation, and/or transformation of the suitable habitats, especially in the lowlands and a recomposition is instead desirable of the habitats and a restoration of the connectivity. In the lowlands, due to the high anthropisation, there is a significant risk that these habitats will be destroyed or damaged. In the mountains, efforts should be taken in order to safeguard the traditional agricultural landscape represented by tree-filled countryside with the presence of hedges and groves. The "old" typology of orchards, with scattered old trees, irregularly alternating with trees of different species and ages is very important for the presence and diffusion of the species: the current orientation towards their elimination, or substitution with linear even-aged plantations, where the trees are small in size could have "disastrous" consequences for the Lesser Spotted Woodpecker especially in the innermost valleys of the Alps, where the high positive influence of old fruit trees has been repeatedly verified. The first nests (late 1980s-early 1990s) were found in large trees of Juglans regia, Malus domestica, Pyrus communis, which, furthermore, are strongly selected throughout the year due to the search for food (including the fruits of the last two species).

In general, the maintenance of a given quantity of dead wood should be provided for, in order to issue various certifications regarding the woodland, which fall within the scope of maintaining a sufficient degree of biodiversity, the sustainability of timber harvesting, the maintenance of a satisfactory level of naturalness etc. Dead or dying plants should therefore be considered, even in managed woodlands, as an indicator of biodiversity necessary for the positivity of the final assessment of the interventions carried out, and not as something to be eliminated or not taken into consideration. These provisions would positively influence the woodland ecosystem by benefitting all the biological components.

Another element that is believed to be important, given the verified increasing trend to frequent urban zones, is the attention to be paid to the management of tree stands of these areas which, often in the hands of unqualified persons become depleted or eliminated (e.g. substituting old trees and/or of native species with young trees of alien species) reducing the ornithological diversity (Rassati, 2015).

In conclusion, it is believed to be necessary to reflect on the fact that, as often happens, the change of the status of a species is a consequence of changes due to unplanned actions and behaviours and, therefore, not consciously chosen. It is instead necessary to takes steps to change the overall sensitivity towards the real natural dynamics in order to provide the possibility of rationally choosing behaviours and actions to carry out.

\section{Acknowledgements}

I would like to thank my father Giancarlo for his fundamental help in data collection. Thanks are also due to Emiliano Maroncelli.

\section{REFERENCES}

Angelstam P.K., Bütler R., Lazdinis M., Mikusiński G. \& Roberge J.M., 2003 - Habitat thresholds for focal species at multiple scales and forest biodiversity conser- vation - dead wood as an example. Annales Zoologici Fennici, 40: 473-482.

Bibby C.J., Burgess N.D., Hill D.A. \& Mustoe S.H., 2000 Bird census techniques. Academic Press, London.

Brazaitis G. \& Pètelis K., 2010 - The woodpecker guild composition in the forests of central Lithuania. Acta Biologica Universitatis Daugavpiliensis, 10 (2): 183188.

Charman E.C., Smith K.W., Gruar D.J., Dodd S. \& Grice P.V., 2010 - Characteristics of woods used recently and historically by Lesser Spotted Woodpeckers Dendrocopos minor in England. Ibis, 152: 543-555.

Ćiković D., Barišić S., Tutiš V. \& Kralj J., 2008 - Woodpeckers in the Croatian Karst Mountains. Bird Census News, 21 (1): 2-15.

Cramp S. (Ed.), 1985 - The Birds of the Western Palearctic, Vol. IV. Oxford University Press, Oxford.

Delahaye L., Derouaux A. \& Delvingt W., 2002 - Habitat modelling: a tool for forest ecology management. A case study of Lesser Spotted Woodpeckers Dendrocopos minor in Belgian Ardenne. Aves, 39: 3-4.

del Hoyo J., Elliott A., Sargatal J. (Eds.), 2002 - Handbook of the Birds of the World, Vol. 7. Lynx Edicions, Barcelona.

Gohli J., Røer J.E., Selås V., Stenberg I. \& Lislevand T., 2011 - Migrating Lesser Spotted Woodpeckers Dendrocopos minor along the coast of southern Norway: where do they come from? Ornis Fennica, 88:121128.

Gorman G., 2004 - Woodpeckers of Europe. A study of the european Picidae. Bruce Coleman, Scarsdale.

Guerrieri G. \& Castaldi A., 2003 - Effetto del fuoco e della gestione selvicolturale sulle popolazioni di Picidae in una pineta costiera mediterranea (Castel Fusano, Roma - Italia Centrale). Rivista italiana di Ornitologia, 73 (1): 55-70.

Hardersen S., 2004 - Habitat usage of woodpeckers and nuthatch (Aves, Picidae, Sittidae). Ricerche naturalistiche a Bosco della Fontana. Quaderni conservazione habitat, 3: 49-59.

Hewson C.M., Amar A., Lindsell J.A., Thewlis R.M., Butler S., Smith K. \& Fuller R.J., 2007 - Recent changes in bird populations in British broadleaved woodland. Ibis, 149: 14-28.

Hogstad O., 2009 - Sexual differences of labour during breeding activities and territory use in the Lesser Spotted Woodpecker Dendrocopos minor. Ornis Norvegica, 32: 42-48.

Julliard R. \& Jiguet F., 2005 - Statut de conservation en 2003 des oiseaux communs nicheurs en France selon 15 ans de programme STOC. Alauda, 73: 345-356.

Kosiński Z. \& Kempa M., 2007 - Density, distribution and nest-sites of woodpeckers Picidae, in a managed forest of Western Poland. Polish Journal of Ecology, 55 (3): 519-533.

Lõhmus A., Kinks R. \& Soon M., 2010 - The importance of dead-wood supply for woodpeckers in Estonia. Baltic Forestry, 16 (1): 76-86.

Meschini E. \& Frugis S. (eds.), 1993 - Atlante degli uccelli nidificanti in Italia. Supplemento alle Ricerche di Biologia della Selvaggina, 20. 
Mikusinski G. \& Angelstam P., 1997 - European woodpeckers and anthropogenic habitat change: a review. Vogelwelt, 118: 277-283.

Miranda B. \& Pasinelli G., 2001 - Habitatansprüche des Kleinspechtes(Dendrocoposminor)inWäldernderNordost-Schweiz. Journal für Ornithologie, 142: 295-305.

Nilsson S.G., Olsson O., Svensson S. \& Wiktander U., 1992 - Population trends and fluctuations in Swedish woodpeckers. Ornis Svecica, 2: 13-21.

Olsson O., Nilsson I.N., Nilsson S.G., Pettersson B., Stagen A. \& Wiktander U., 1992 - Habitat preferences of the Lesser Spotted Woodpecker Dendrocopos minor. Ornis Fennica, 69: 119-125.

Olsson O., Wiktander U., Malmqvist A. \& Nilsson S.G., 2001 - Variability of patch type preferences in relation to resource availability and breeding success. Oecologia, 127: 435-443.

Ottvall R., Edenius L., Elmberg J., Engström H., Green M., Holmqvist N., Lindström Å., Pärt T. \& Tjernberg M., 2009 - Population trends for Swedish breeding birds. Ornis Svecica, 19: 117-192.

Rassati G., 2005a - Distribuzione del picchio rosso minore Dendrocopos minor in Friuli-Venezia Giulia. Avocetta, 29 (Numero speciale): 202.

Rassati G., 2005b - Limiti altitudinali del Torcicollo Jynx torquilla e del Picchio verde Picus viridis in Carnia, Canal del Ferro e Valcanale (Alpi Orientali, FriuliVenezia Giulia). Picus, 60: 129-131.

Rassati G., 2008 - Responsiveness to acoustic stimulations and density of Great Spotted Woodpecker Dendrocopos major, of Green Woodpecker Picus virdis and of Lesser Spotted Woodpecker Dendrocopos minor in a sample area of Carnia (Carnic Alps, Friuli-Venezia Giulia, North-eastern Italy) (Years 1993-2003). Gli Uccelli d'Italia, 33: 33-51.

Rassati G., 2009 - Densità nelle Alpi Carniche e limiti altitudinali in Friuli-Venezia Giulia di Picchio rosso maggiore Dendrocopos major, Picchio verde Picus viridis e Picchio rosso minore Dendrocopos minor. Alula, 16 (1-2): 778-780.

Rassati G., 2012 - Nuovi dati sulla distribuzione del Picchio rosso minore Dendrocopos minor in Veneto. Gli Uccelli d'Italia, 37: 115-116.

Rassati G., 2014a - Responsiveness to acoustic stimulation, distribution and habitat preferences of the Greyheaded Woodpecker, Picus canus, and the Three-toed Woodpecker, Picoides tridactylus, in Friuli-Venezia Giulia (North-eastern Italy). Rivista italiana di Ornitologia, 84 (1): 41-52.

Rassati G., 2014b - Comparison between two methods used to census the Picidae. Proceedings of the XVI Italian Ornithology Conference, Cervia-Milano Marittima (RA), 21-25 September 2011. Scritti, Studi e Ricerche di Storia Naturale della Repubblica di San Marino: 417-418.

Rassati G., 2015 - "Sylviphobia" and urban bird populations. Proceedings of the XVII Italian Ornithology Conference, Trento, 11-15 September 2013. Ed. MUSE, Trento: 143-144.

Reif J., Storch D., Voříšek P., Št’astný K. \& Bejček V., 2008 - Bird-habitat associations predict population trends in central European forest and farmland birds. Biodiversity Conservation, 17: 3307-3319.

Riemer S., 2009 - Population densities and habitat use of woodpeckers in a Danube floodplain forest in Eastern Austria. Diplomarbeit, Universität Wien.

Rochè J.C., 1990 - All the bird songs of Britain and Europe. Sittelle, Mens.

Smart J., Taylor E., Amar A., Smith K., Bierman S., Carpenter J., Grice P., Currie F. \& Hewson C., 2007 Habitat associations of woodland birds: Implications for woodland management for declining species. RSPB Research Report, 26.

Smith K.W., 2007 - The utilization of dead wood resources by woodpeckers in Britain. Ibis, 149 (Suppl. 2): 183-192.

Spitznagel A., 1990 - The influence of forest management on woodpecker density and habitat use in floodplain forests of the Upper Rhine Valley. In: Conservation and management of woodpeckers populations. Carlson A. \& Aulen G. (eds). Dept. of Wildlife Ecology, Swedish Univ. of Agricultural Sciences, Report No. 17, Uppsala.

Stenberg I. \& Hogstad O., 1992 - Habitat use and density of breeding woodpeckers in the 1990s in More og Romsdal county, western Norway. Cinclus, 15 (2): 49-61.

Tiainen J., 1985 - Monitoring bird populations in Finland. Ornis Fennica, 62: 80-89.

Wesołowski T., 2011 - "Lifespan" of woodpecker-made holes in a primeval temperate forest: A thirty year study. Forest Ecology and Management, 262: 1846-1852.

Wesołowski T., Tomiałojć L., Mitrus C., Rowiński P. \& Czeszczewik D., 2002 - The breeding bird community of a primaeval temperate forest (Białowieża National Park, Poland) at the end of the $20^{\text {th }}$ century. Acta Ornithology, 37: 27-45.

Wiggins D., 2004 - American Three-toed Woodpecker (Picoides dorsalis): a technical conservation assessment. USDA Forest Service, Rocky Mountain Region.

Wiktander U., Nilsson I.N., Nilsson S.G., Olsson O., Pettersson B. \& Stagen A., 1992 - Occurrence of the Lesser Spotted Woodpecker Dendrocopos minor in relation to area of deciduous forest. Ornis Fennica, 69: 113-118.

Wiktander U., Olsson O. \& Nilsson S.G., 2000 - Parental care and social mating system in the Lesser Spotted Woodpecker Dendrocopos minor. Journal of Avian Biology, 31: 447-456.

Wiktander U., Olsson O. \& Nilsson S.G., 2001a - Age and reproduction in Lesser Spotted Woodpeckers (Dendrocopos minor). Auk, 118 (3): 624-635.

Wiktander U., Olsson O. \& Nilsson S.G., 2001b - Seasonal variation in home-range size, and habitat area requirement of the Lesser Spotted Woodpecker (Dendrocopos minor) in southern Sweden. Biological Conservation, 100: 387-395.

Winkler H., Christie D. \& Nurney D., 1995 - Woodpeckers. A Guide to the Woodpeckers, Piculets and Wrynecks of the World. Pica Press, Mountfield.

Wübbenhorst J. \& Südbeck P., 2003 - Woodpeckers as indicators for sustainable forestry? First results of a study from Lower Saxony. Nationalpark Berchtesgaden Forschungsbericht, 48: 179-192. 